Research, part of a Special Feature on Resilience and Vulnerability of Arid and Semi-Arid Social Ecological Systems

\title{
China's Grassland Contract Policy and its Impacts on Herder Ability to Benefit in Inner Mongolia: Tragic Feedbacks
}

\author{
$\underline{\text { Wenjun }} \mathrm{Li}^{1}{ }^{\text {and Lynn Huntsinger }}{ }^{2}$
}

\begin{abstract}
Northern China's grasslands have been losing productivity since the 1980s, when a policy known as the "grassland contracting policy" allocated commonly used grazing lands to individual herder households. Examined here is the connection between implementation of the grassland contracting policy and the loss of grassland production using the analytic concepts of ability to benefit and community failure. A gacha (village) of the Sunite Left Banner of the Xilingol League in Inner Mongolia is used as a case study to compare herder ability to benefit from rangeland resources during adverse climate events before and after policy implementation. Social-ecological resilience, access to social and ecological assets, and institutions supporting crisis relief have been affected. We find that the privatization of grassland use rights has weakened pastoralist ability to benefit from rangelands by weakening or dismantling what are identified as the rights-, structure-, and relations-based abilities that enabled pastoralists to cope with nonequilibrium conditions. This has led to a community failure that engenders feedbacks of increased impoverishment and environmental deterioration. The inflexible boundaries of quasi-private household property rights have caused the pastoral system to lose capacity to respond to drought and weather events through the flexibility of "otor" and other forms of herd movement, increasing vulnerability to environmental change.
\end{abstract}

Key Words: arid lands; climate change; community failure; Inner Mongolia; pastoralism; privatization; property rights; rangelands

\section{INTRODUCTION}

Nearly $42 \%$ of China is natural grassland, comprised of a total of 393 million hectares. Currently, $90 \%$ of usable grasslands are considered "degraded" because of species change and productivity loss (Ministry of Agriculture 2007). Although the government has invested large sums to mitigate and control this problem, outcomes have been described as a "partial improvement amidst overall deterioration" (Ministry of Agriculture 2007:1). Most severely affected are the arid and semiarid provinces of Inner Mongolia, Ningxia, Xinjiang, Qinghai, and Gansu. Much of this area has been grazed for thousands of years as part of pastoral systems whose social institutions enabled herders to cope with the geographical and temporal unpredictability of forage production across vast areas (Fernandez-Gimenez and Le Febre 2006). Government-initiated property rights restructuring over the last 30 years has increased the vulnerability of pastoral social-ecological systems to environmental variability, including climate change.

As noted by many scholars (Humphrey and Sneath 1999, Sneath 2000, Ho 2001, Williams 2002), the decline in productivity of China's grasslands and its negative impacts on herder livelihoods is inseparable from grassland property rights reform that started in the 1980s. The "livestock contract program" of the early 1980s was copied from farmland programs (Li et al. 2007) with the goal of preventing what was termed "Ren Chi Da Guo Fan" (everyone eating from the same big pot, no matter what their contribution), which was believed to be the root cause of low production efficiency because of the lack of a work incentive. The livestock contract program attempted to address the perceived "people eating from the same pot" problem by allocating livestock held in common as a legacy of the collective system to individual households by contract. However, although this policy solved the 
problem of Ren Chi Da Guo Fan, and increased livestock production dramatically, it led to grassland degradation from "livestock eating from the same pot" ("Xu Chi Da Guo Fan"). As a result, a new initiative, the "grassland contracting policy" was implemented in the middle and late 1980s (Chen 1987, Li et al. 2007). Grasslands were allocated to groups of households, known as "hot" in Inner Mongolia and Mongolia. Hot is a Mongolian word that originally referred to a production unit of a number of mobile herder households with kinship relationships. Since the settlement policies of the collective era, it now generally refers to residential areas where a hot is several adjacent households. In the 1990s, grasslands were further allocated to individual households by contract. Underlying each initiative was the assumption that by clearly defining individual property rights, rights holders would change their behavior and invest in their enterprise and the grasslands in a way that would promote sustainable production (Taylor 2006). Unfortunately, this clarification of property rights did not cause herders to manage grasslands as was expected, so the government now sets stocking rates for pastoralists that have been on the grasslands for multiple generations. These "balancing animals and grass" programs are commonly resisted by herders (Li and Zhang 2009).

China's grassland contracting policy, first implemented in Inner Mongolia, coincides with a global trend of privatizing land. Over the past two decades, the less developed world has experienced widespread pressure to assign parcels of land held in common to individuals (Sjaatad and Cousins 2008). The intention is to pursue efficiency and fairness through establishing market-oriented land property systems based on privately owned land (Ybarra 2008). Unfortunately, in herder economies, such fragmentation puts in jeopardy socialecological institutions that equip herders to persist despite unpredictable droughts and severe weather, institutions that could also buffer the impacts of climate change.

It is widely understood that unanticipated climatic events are a typical feature of pastoralist environments. To persist and avoid destabilizing consequences, pastoralists must be able to rapidly respond to such events by accessing alternative resources (Roe et al. 1998). A lack of response can result in the destruction of the pastoralist system, while a slow response creates a lag time that will result in the loss of animals, and a subsequent delay in the ability to rebuild flocks when conditions improve. To analyze herder capacity to respond during and after the implementation of the grassland contracting policy, this study takes one "gacha" (village) of the Sunite Left Banner, Xilingol League in Inner Mongolia as a case study and examines how the privatization of grassland use rights has resulted in the overall deterioration of this pastoral system and the grasslands, which we call the "tragedy of privatization." Theories of rights and ability to benefit (Ribot and Peluso 2003) are used to explain some of the mechanisms by which arid lands subsistence herders, and pastoral social-ecological systems, are disadvantaged and put at risk through privatization programs (Dougill et al. 2010). Further, the theory of community failure (McCay and Jentoft 1998) is applied to analyze the underlying mechanisms that weaken the ability of herders to benefit from grassland resources.

\section{PROPERTY RIGHTS AND ABILITY TO BENEFIT}

The primary intent of establishing a private property rights system is to secure the right of the rights holder to benefit from his or her property, but whether the rights holder can benefit or not depends on his or her abilities, and access to capital, labor, and other resources. Ribot and Peluso's work (2003) on rights and access provides an analytic frame for understanding how the grassland contracting policy impairs the ability of herders to benefit from rangelands. For those whose livelihoods depend solely on natural resources, the ability to benefit from the resources is as important or more important than the right to benefit (Ribot and Peluso 2003). For example, a property rights allocation can grant someone the right to benefit from a piece of land, but if the rights holder does not have the ability to provide labor or capital, he or she will not be able to benefit from the land to maintain his or her livelihood. Of course, right and ability are interlinked to a certain extent, but a right is only one aspect of safeguarding the ability to benefit, while ability is embedded in a web of mechanisms, or means, processes, and relations, and is subject to the impacts and outcomes of social relations including reciprocity, friendship, trust, obligation, and dependence (Ribot and Peluso 2003).

The theory of community failure (McCay and Jentoft 1998) has further explanatory value in 
understanding how the ability of herders to benefit from resources is weakened from the perspective of the social and political relations, as well as changing historical contexts, within which property rights are embedded. These include the institutions and social relations that mediate the interactions of pastoralist communities with rangeland environments, and when these relationships break down, according to this argument, community failure, rather than market failure, better explains the resulting environmental deterioration. The social relations characteristic of pastoral systems have been well documented in the literature and include reciprocal social relations, flexibility, and mobility (FernandezGimenez and Le Febre 2006, Huntsinger et al. 2010). These relations are part of what give pastoral systems their resilience.

Resilience can be defined as the capacity of a system to absorb disturbance and reorganize while undergoing change so as to still retain essentially the same function, structure, identity, and feedbacks (Walker et al. 2004). Resilient social-ecological systems incorporate diverse mechanisms for living with, and learning from, change and unexpected shocks (Adger et al. 2005), mechanisms that echo the "web of social relations" described by Ribot and Peluso (2003), and that are critical to explaining environmental outcomes according to McCay and Jentoft (1998). Though the definition and applicability of the term have been contested, we believe it offers useful insight into the functioning of pastoralist societies on arid rangelands.

The 264 million ha of natural rangeland in China's northern arid and semiarid areas, where annual average precipitation is less than $400 \mathrm{~mm}$, account for nearly $67 \%$ of the country's grasslands (Ministry of Agriculture 1996). Nonequilibrium models generally better explain ecological dynamics than do equilibrium-based models when rangeland is at the arid end of the gradient from dry to mesic conditions (Briske et al. 2005, Vetter 2005). Nonequilibrium or disequilibrium models posit that abiotic factors such as weather, soil structure, erosion, and water table depth are the dominant drivers of rangeland productivity and species composition (Ho 2001), and that the relationship with livestock grazing is often nonlinear (Ellis and Swift 1988, Westoby et al. 1989). On arid rangelands, spatial and temporal variation in water and forage resources is high, annual production is as unpredictable as rainfall and temperature patterns, and extremes of precipitation or temperature are not uncommon. Nonequilibrium models also posit the existence of multiple stable (within a management time frame) vegetation states maintained largely by abiotic factors, rather than a single endpoint climax or stable equilibrium state (Westoby et al. 1989, Stringham et al. 2003) created mostly by biotic interactions.

The goal of establishing a fixed carrying capacity or stocking rate that will keep livestock numbers and vegetation in balance is nullified when highly variable rainfall is the main vegetation driver and there is no predictable equilibrium state (Ellis and Swift 1988, Behnke and Scoones 1993). Pastoralist systems have developed opportunistic and flexible institutions and practices that have enabled their persistence on such rangelands for the long term (Scoones 1994). These include feedbacks and connections that buffer change and uncertainty, allowing pastoralists to maintain a relatively reliable flow of resources from a relatively unreliable environment (Roe et al. 1998). Stabilizing feedbacks create the response, flexibility, and learning that are characteristic of resilient systems. For example, forage scarcity often demands that pastoralists move to new range to maintain animal health, long before vegetation has been significantly impacted by grazing.

\section{STUDY AREA}

The case study village, Gacha B, is in Sunite Left Banner (SLB), Xilingol League, Inner Mongolia Autonomous Region, a desert-steppe area (Fig. 1). From 1957-2006, average annual precipitation was $189 \mathrm{~mm}$ with high inter-annual variability (Meteorology Bureau, SLB, unpublished data). The gacha is 70,000 ha or 1.05 million mu (1 hectare = $15 \mathrm{mu}$; Inner Mongolia Survey and Design Institute for Grasslands, unpublished data).

Herders in Gacha B are mostly ethnic Mongolian. In 2006, there were 105 registered households with a total of 372 individuals. About 75 of these households were in fact living in the gacha and supporting themselves through animal husbandry. The remaining households had moved to urban areas and depended on income from wage labor after losing all their animals as a result of several years of drought and the recent fencing and exclusion of grazing from large areas, a practice implemented by the government when the grassland contracting system failed to halt grassland productivity loss and 
Fig. 1. Sunite Left Banner (sometimes referred to as Sonid Left Banner) is located within the Xilingol League of Inner Mongolia, China.

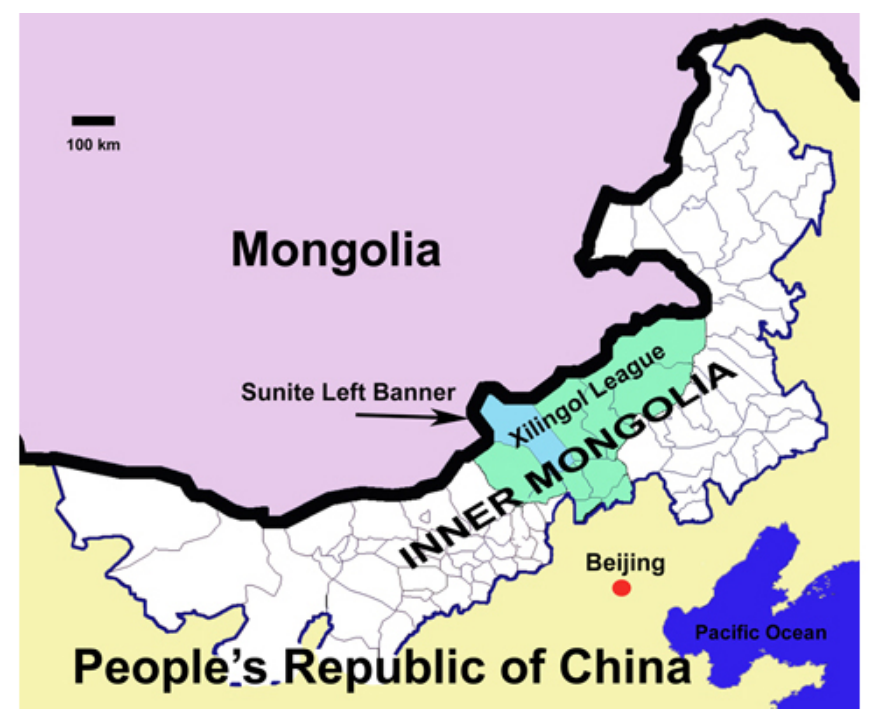

species change (Bijoor et al. 2006). Over the last 50 years, the number of livestock peaked at 54,525 sheep units in 1999, but drought and exclosure resulted in a decline to 34,153 sheep units by June 2006 (a sheep unit is the equivalent of one standard, mature sheep). Typical of this region, Gacha B has frequent adverse weather events. From 1967 to 2006, severe events, either strong snowstorms or extreme drought, occurred every four or five years (Meteorology Bureau, SLB, unpublished data). The local government has taken steps to help alleviate losses from these disasters, for example, by helping to put in wells, encouraging herders to plant improved forage, facilitating bank loans, providing veterinary care, encouraging livestock breed improvement, and so on. However, natural disasters are still the most important cause of livestock death in SLB, and it is clear that the highly variable and uncertain weather has a decisive impact on local livestock husbandry. Traditionally, local herders cope with adverse weather events through a method called "otor," where herders temporarily move their livestock away from local rangelands to access better range elsewhere (Xie and $\mathrm{Li} 2008)$.

In 1984, Gacha B underwent the first round of grassland contracts, allocating rangelands to hot, i.e., a group of households. There were 940 thousand $\mathrm{mu}$ of grassland contracted to hot while 100 thousand mu were kept in collective use. In 1984 ,
Gacha B had 58 households totaling 176 persons in 16 hot. Each hot received a "Certificate of Grassland Contracting for Use Rights" with a map of the contracted pasture. This certificate clearly defined the boundary and scale of each hot grassland.

The second round of grassland contracting started in 1996. The hot grasslands were divided and contracted to each household independently. In 1999, the Inner Mongolia Autonomous Region Government granted a "Certificate of Grassland Contracting for Operation Rights (CGCOR)" to each household. All 69 herder households in Gacha $\mathrm{B}$ at the time received the certificate. The contract duration was stipulated as 30 years, from 30 December 1996 to 2026. The area of contracted grassland was inventoried and categorized for different uses, including grazing, hay cutting, and forage cultivation, and the quality of the land was rated by the local government, with three ratings indicating the quality of grass production. The contractee's gacha cannot take back or change the contracted grassland unilaterally. If a slight adjustment is needed among a few households, it must be registered in the administration office of the "sum," the next higher level of government above gacha, and the equivalent of an agricultural township (Table 1). 
Table 1. Administrative units in Inner Mongolia, China.

\begin{tabular}{lll}
\hline \hline Unit (Mongolian) & Name & Size (approx.) \\
\hline Province & Inner Mongolia & $118.3 \mathrm{~m}$ ha \\
League (Aimag) & Xilingol & $20.3 \mathrm{~m}$ ha \\
Banner/county (Hoshu) & Sunite Left Banner & $3.3 \mathrm{~m}$ ha \\
$\begin{array}{l}\text { Sumu/township or formerly, commune } \\
\text { (Sum) }\end{array}$ & Bayanwula & 770,200 ha \\
Gacha/village (Gacha) & Gacha B & 70,000 ha \\
Hot (Hot) & Group of households & av. approx. 4100 ha \\
Household & Herder family & av. approx. 1080 ha \\
\hline
\end{tabular}

\section{METHODS}

Field surveys were conducted in Gacha B in April 2006, July and August 2007, and July 2008. Structured and open-ended interviews and participant observation at the community level were used to collect data and information on changes to otor caused by implementation of grassland contracts, focusing on herder ability to access alternative resources during adverse climate events. Herders were asked about property rights, information sources, levels and types of knowledge, capital, labor, markets, and social relations. Of the 75 herder households, 28 were visited and interviewed (Fig. 2). Of these, two households had lost all their livestock because of continuous bad weather, and were living on rangeland rented to others or renting livestock from others to herd. Households were sampled at random locations to exclude the impacts of variation in grassland characteristics on livestock production. In arid areas like Gacha B, there is significant resource spatial heterogeneity, both in primary production and water sources, even on a small spatial scale, which significantly influences secondary (livestock) production.

Local government officials in Sunite Left Banner were interviewed to collect historical data on precipitation, climate, and livestock production. Sources included individuals in the Bureau of
Statistics, the Bureau of Livestock Husbandry, the Station for Grassland Management and Herder Livelihoods, and the Grassland Survey Station.

Using the analytic framework of Ribot and Peluso (2003), the ability to benefit was classified into three categories. The first category is rights-based ability, i.e., the ability that is sanctioned by law, custom, or convention. The second is structure-based ability, including technology, capital, market, labor, and knowledge. The third is relations-based ability, including authorities, identities, and social relations. For each of these three aspects, qualitative description is used to present the change in herder ability to benefit following household level contracting. Finally, the concept of community failure (McCay and Jentoft 1998) is used to examine how changes in social relations have contributed to the increased vulnerability of the pastoral socialecological system.

\section{RESULTS}

\section{Loss of rights-based ability to benefit}

Despite providing a form of private ownership of rangelands to herder households, the grassland contracting system has reduced herder rights-based ability to benefit from rangeland resources. In the collective era (mid-1950s to 1982), both livestock 
Fig. 2. Mongolian yurt and brick house. As part of the "Grassland Contracting Policy", herders are encouraged to move into residential blocks. Although the government helps them to build a modern brick house, many elderly Mongolians still like to live in their traditional yurt in the summertime.

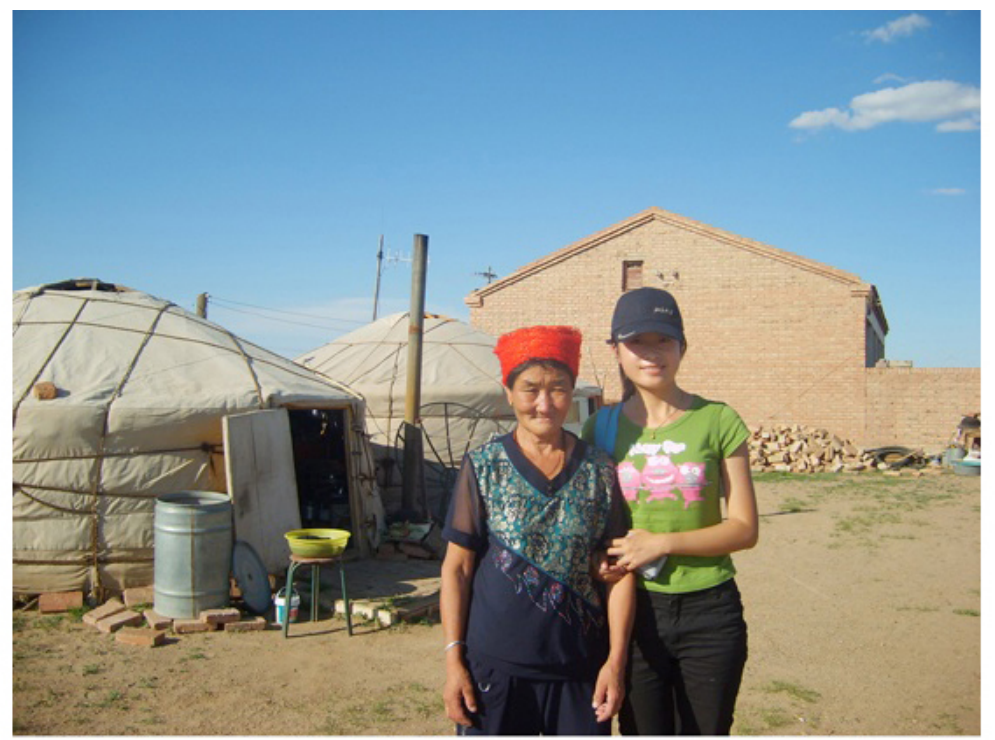

and rangeland were owned by the gacha, at that time called a production team. On behalf of the collective, the gacha had the right to use and manage the rangeland and to exclude other users from it. However, this de jure right of exclusion was rarely used. As pastoralist interviewee Zhaolumen (real names are not used) recalled:

In the collective era, we grazed inside the gacha rangeland most of the time. However, when adverse weather happened and our own rangeland couldn't meet forage needs, we conducted otor and moved livestock to other gacha or even other sum as coordinated by collective cadres. There were no conflicts over boundaries at that time.

In fact, besides frequent short distance otors, there were five long distance otors between 1964 and 1984 in Gacha B, when all the livestock of the Gacha were moved to better rangeland more than $200 \mathrm{~km}$ away. Although the boundary between the neighboring gachas was clear, it was not fixed. Instead, it was adjustable in response to variable weather conditions. When livestock needed to move outside gacha rangeland, cadres of the sum, called a commune at the time, had the authority to manage and coordinate livestock movements within the district. In this way, gacha herders could access resources at a larger scale.

During the first round of contracting, the management and exclusion rights shared among the Gacha B's pastoralists in the collective era were distributed to hots. Each hot household obtained the right to use hot grasslands, and each hot had management and exclusion rights at the hot level but gave up rights to resources outside the hot. Therefore, the basic rangeland unit with exclusive rights was reduced to the hot instead of the gacha. For Gacha B, even though the gacha still owned the grassland, according to the new grassland contracting stipulations, it no longer had the right to adjust the boundaries of hot rangelands. Maps created inflexible, "hardened" borders enforced by local authorities. Similarly, after the second round of contracting, exclusion rights once possessed by the hot were completely delegated by the state to smaller household grasslands. Each herder household now has complete use, management, and exclusion rights over the contracted grassland, but has lost all rights to those outside of the contracted household-level grassland. Thus, when adverse weather events happen, the household is no longer guaranteed the right, by convention or the state, to access better resources outside of the family 
rangeland. When herders need to conduct otor, they have to pay rent to the owner of the destination rangeland in advance. The higher transaction costs weaken herder ability to cope with the highly variable environment (Xie and Li 2008). Fixed boundaries, defined and enforced by the state, have replaced flexible boundaries enforced by convention and facilitated by the state. The loss of rights to use larger scale resources has reduced herder ability to benefit from rangelands.

\section{Breakdown of structure-based ability}

In addition to loss of rights-based access to larger scale resources, the privatization of rangelands also changed herder structure-based ability to benefit from information, knowledge, technology, markets, capital, and labor. Information networks and ability to respond quickly have been identified as an important part of coping with the unpredictability typical of arid grasslands (Roe et al. 1998). Before the grassland contracting system, in a disaster year, information about rangeland conditions at a larger spatial scale could be communicated quickly between gachas, and even sums if needed, which was essential when searching for otor rangeland. Household level contracts mean that each household now must independently search for and evaluate possible destinations for moving their livestock. Limited access to information and knowledge networks means that decisions may be delayed, or based on poor, more spatially constricted information, resulting in livestock losses. Many old herders recalled that in the collective era the otor was organized by the gacha quickly and that this greatly reduced the loss of livestock during disaster years. However, as a result of household contracts, it is now not so easy for households to obtain accurate information quickly about otor rangeland. A herdsman named Bater explained that:

Last year [2006] I went out early in June to try to seek a place to otor, butfailed. Quite often you hear of a possible pasture in some place, but you can never believe what you hear. You need to go there and see the real situation. Like in my case, once I heard of a place that would allow otor for a lower price, so I rode a motorcycle to the place to see, and found the price was actually very high for what was there. Due to this delay in finding suitable rangeland, I couldn't practice otor on time last year.
Market and environmental variability create further uncertainty. In the 2006 drought, almost all households in Gacha B conducted otor. High demand for alternative rangeland meant that according to interviewees, competition to rent was fierce, driving up prices. Because there was a rush to sell livestock in early summer when a drought started to become apparent, prices were less than half of the normal market price in late autumn. These low returns further reduced herder resources and ability to invest in finding otor grasslands.

Poor information, and market and environmental uncertainty, combine to increase the risk of livestock staying in the stricken home rangeland too long. The delays described by Bater are devastating to herders and livestock, as well as hard on the grassland. Respondents stated that during the severe weather, livestock lost condition and became very weak. Some households lost more than 10 sheep per day before they were able to otor, and some households simply sold their livestock at a low price of 100 Yuan (US\$14) per sheep, 280 Yuan (US\$ 40) per ewe with lamb, and 1000 Yuan (US\$ 140) per horse. Each day they remained on the stricken home rangeland during the drought caused the loss of dozens of sheep. A destabilizing feedback loop emerged where losses of sheep in turn further restricted the capital available to the herders, making them even more vulnerable to environmental events and less able to escape local conditions.

Large scale fencing is an introduced technology that has accompanied the contracting of the grassland to demarcate household rangelands with inflexible boundaries. In 2006, herders reported that when they were moving to otor rangelands, the livestock were often so weak that they had to be moved with rented vehicles. During the return trip after otor, most herders herded their livestock back home, saving some transportation expenses. They had to herd along the main road to avoid the fences and the cost of using pasture on the way. In many places a grazing ban has been implemented within $500 \mathrm{~m}$ of both sides of the road (Bijoor et al. 2006), so the herders had to speed the livestock along to avoid being fined. Before, livestock could be herded across the shortest distance. Fences resulting from privatization and grazing exclusion have increased the costs and risks of otor and reduced the benefits (Fig. 3).

In pastoral areas, labor is typically in short supply, such that pastoral societies characteristically rely on 
Fig. 3. Fence and cattle in Gacha B. Fences are used to demarcate property boundaries since the "Grassland Contracting Policy" was implemented. They fragment the rangeland and block the movement of animals, and represent the creation of fixed rather than fuzzy boundaries.

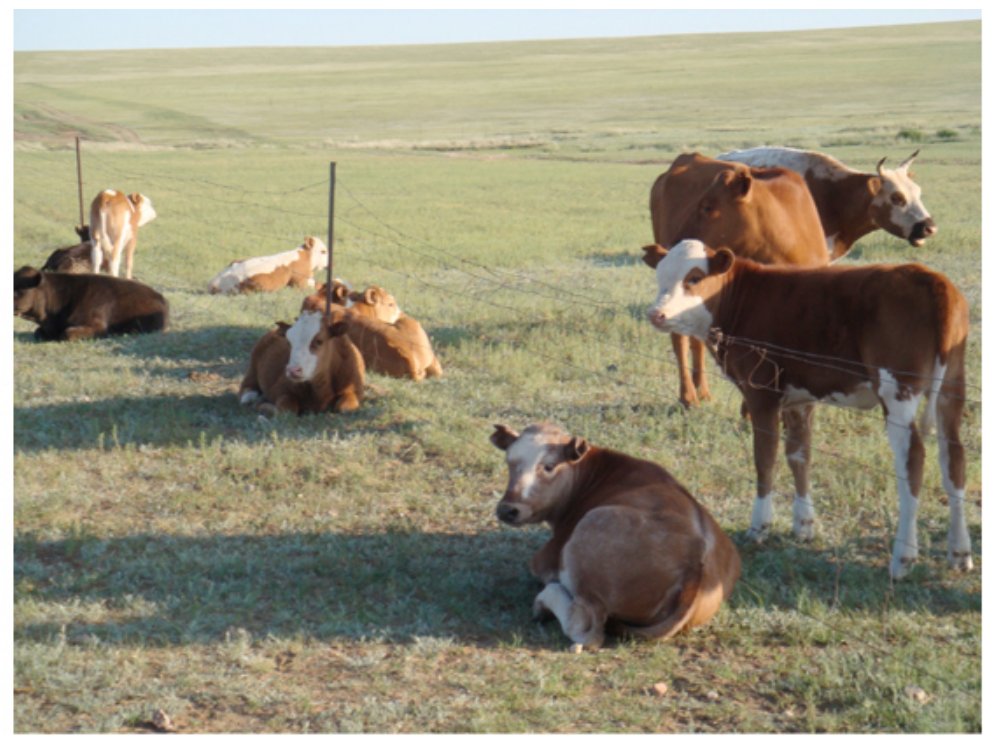

cooperative labor. For example, maintaining household access to all of five traditional livestock species, i.e., cattle, sheep, goat, horse, and camel, of the Mongolian Plateau requires cooperation among households, because a single household cannot adequately care for all of them. A cooperating group of herders can allocate labor to each type and class of animal, such that the requirements for each species can be better met. Horses can be grazed where the forage is best for them, while goats, for example, can be taken to areas with brush and other favored forage. Animals with young can be grazed in areas that are most beneficial to milk production and so forth. When a household has to graze herds independently, this husbandry is not possible. Cooperative arrangements for labor ended after household-level contracting of the grassland, resulting in the simplification of herd structures to the point where households raise mostly sheep. When a herd becomes simplified, the grassland is less efficiently used, because species have different diets and grazing patterns (Walker 1994). If only sheep are grazed, they will eat primarily plants palatable to sheep, and plants favored by other livestock will be less used, leading to a less efficient and unbalanced use of the spectrum of available plant species (Coppock et al. 1986). Like crop mono-cultures, single-species herds are more vulnerable to disease and pests (Thrupp 2000), and as with farmers producing only a single crop, households relying on a single form of livestock are less resilient to variations in forage supply, weather, and changes in market prices for particular species or product (Thrupp 2000, Fernandez-Gimenez and Le Febre 2006).

Once grasslands were broken up, independent households became more subject to the general conditions of capital availability, access to technology, labor limitations, and markets. It is very difficult for households marketing small numbers of stock and buying small amounts of feed or forage to be competitive in the market, for example. Also, because of their limited capital and technology, it is difficult for households to independently participate in industrial production of dairy and meat products.

\section{Collapse of relations-based ability}

Social relations are part of the web of means, processes, and relations that support ability to benefit (Ribot and Peluso 2003). The grassland contracting system has also lead to a loss of relations-based ability to benefit, because formerly cooperative relationships have been transformed 
into competitive relationships. The concept of community failure allows a nuanced examination of this shift.

As McCay and Jentoft (1998) point out, resource decline may be due to imperfect property rights, but also can be caused by a collapse of social bonds that they believe leads to community failure, i.e., conflict among competing groups, opportunism by privileged elites, and internally or externally induced differences in the ability of groups to make and enforce institutional arrangements. They identify the state and the market as important potential instigators of community failure. The state, through bureaucratic involvement in resource management, creates vertical linkages between the user and the government that overwhelm horizontal linkages such as those that users formerly had with each other. Cooperative and symbiotic relationship patterns are transformed into competitive and positional relationships, causing users to become dependent on their relationship with the government and to develop conflicts with one another (McCay and Jentoft 1998). The development of community failure after grassland contracting was evident in Gacha B.

Before household contracting, herders related that reciprocal relations acted as a guarantee of access, i.e., a rights-based access, to larger scale resources for coping with adverse weather events. However, reciprocal social bonds were based on an expectation or trust among herders that each herder would allow access to their pasture for other herders in need, because in turn they could expect the help of others when weather conditions were poor in their own area. These relationships allowed herders the flexibility to adjust grassland boundaries when needed. In Gacha B, even when households are next to each other, one household may have drought the same year that the adjacent household has lush grass because of highly local rainfall in the key season. In the 2008 summer survey, a herdsmen suffering from drought told us that he could often see dark clouds over his neighbor's pasture, while there was not one drop of rainfall on his.

The reciprocity underlying traditional otor is illustrated by the way otor was transacted among herders. Traditionally the herder practicing otor, the otor-maker, would "leave several livestock to the otor pasture provider as a gift at the end of the otor," as herdsman Norebu told us. The livestock were given to the pasture provider as a thank you gift, not as a precondition of being allowed to practice otor. In addition, the otor itself helped to develop social bonds and trust among herders. In the process of using otor rangeland together, the relationship between the pasture-providing herder and the otormaker was deepened through daily cooperative work in animal husbandry. According to Norebu's recollections, the pasture provider and otor-maker comanaged the livestock, sometimes even for a complete annual cycle of livestock production. After household level grassland contracting was implemented, herders had to become relatively independent in livestock production because of the fragmentation caused by the fenced boundaries of household rangelands. With cooperation reduced and communication between herders weakened, herders told us that reciprocal bonds based on friendship, solidarity, and trust fractured, which has hindered the development of new cooperative relations in response to the change in scale of household grassland access. Reliance on marketbased relationships to permit flexibility is now attempted. Instead of the traditional reciprocal help, otor pasture providers now request cash for pasture use, and in most cases, ask otor-makers to pay before using the pasture. However, not every otor-maker is able to afford the charge, especially in disaster years, so they have to turn to high interest illegal loans, imposing further heavy burdens on households already suffering from weather disasters, and feeding back into increasing vulnerability to climatic events. Some households now charge a pass-by fee or tariff when otor animals pass through their grasslands, and may charge an animal watering fee ranging from 0.5 (US\$ 0.07) to 1 Yuan (US\$ 0.14) per sheep. If the passing herder doesn't pay, sheep are seized until the charges are paid.

The otor no longer functions to develop and deepen cooperative relationships among herders, and tends to be terminated earlier than under the precontract system. The otor-maker may drive his livestock back home before the home rangeland is completely restored to save on fees. McCay and Jentoft (1998) point out that the commercialization of reciprocal ties can lead to the breakdown of traditional management through the collapse of traditional moral authority. The market redefines social relations, which become instrumental and utilitarian, with social interaction that is strategic and ego-centered. 
Because social bonds have broken down and herders no longer feel a responsibility toward each other, agreement or contract violations now often happen that were previously unimaginable. A herder named Ale reported that when he tried to seek otor rangeland in 2006:

...we [Ale and the lessor] had agreed to a charge of 8 Yuan [US\$ 1.1] per sheep per month, but later when another herder promised to pay 10 Yuan [US\$ 1.4] per sheep per month, the lessor immediately violated our agreement and rented to the herder offering more money. Then I had to search for another pasture.

From our survey, $12 \%$ of households who practiced otor in 2006 were delayed because of agreement violations and had to spend precious time searching for another pasture. More than one third of otor practicing households spent more than 5 days searching, and suffered animal losses because they had to remain too long on stricken home rangeland.

When otor-makers have a disagreeable experience with price gouging or agreement disputes, a feedback loop is created that further dismantles the social relations upon which otor depends. When climate conditions change, and otor-makers become the potential pasture providers, they may be reluctant to participate in a reciprocal relationship of the traditional, nonmonetary type, further reducing herder access to otor pastures. Formerly strong social norms have been changed, and the feedback that herders get, for example, unreliable contracting and unavoidable loss of animals, supports further deterioration of relationships that once provided the flexible and swift response to weather events that conserved both animals and environment. In the long run, this feedback loop is likely to cause further impoverishment of households and loss of ability to use grasslands, as well as damage to the grasslands.

The practice of otor and cooperative animal husbandry are based on herder relationships that include norms and expectations of mutual trust and reciprocity. However, the forces of the state and the market have weakened these relations, leading to a decline in relations-based ability to benefit.

\section{DISCUSSION}

An elderly interviewee pointed out to us that at the outset of the change to household grassland allocations, herder response could be characterized by the statement that "for the first time in thousands of years we have our own grassland." As time has passed, more and more herders report that they are confused and concerned as they see their livelihood decline and their communities decay (Li and Zhang 2009). This case study makes it clear that without the ability to benefit, a certificate giving a household the right to a parcel of grassland is meaningless. The concept of ability to benefit helps to explain how interventions in pastoralist systems often seem to create or exacerbate, rather than solve, degradation problems and have often left people worse off than before (Ellis and Swift 1988, Vetter 2005).

As is the case with privatization efforts that have accompanied rangeland development projects around the world (Sandford 1983), the argument for the grassland contracting policy is that the exclusive use of rangeland will lead to long-term investment and protection of the grasslands. However, there is a difference between "exclusivity" in theory and "excludability" in reality. Whether resources can be used exclusively or not depends on the nature of the resource itself. Studies of nonequilibrium systems (Ellis and Swift 1988, Westoby et al. 1989, Vetter 2005) reveal that the spatial and temporal heterogeneity of rangeland and its lower productivity in arid areas causes the cost of exclusiveness to exceed its benefits (Banks 2001). Herders cope with the spatial variability and temporal unpredictability of arid rangelands through opportunistic and flexible grazing strategies that allow access to resources across a large spatial scale (Scoones 1994, Gillson and Hoffman 2007, Zhang and Li 2009). These strategies are embedded within social relationships like reciprocal pasture sharing, in this case the otor described by interviewees.

Studies of rangeland management systems before privatization in Africa and Mongolia (FernandezGimenez 1999, Humphrey and Sneath 1999, Fernandez-Gimenez 2002, Behnke 2008, Mwangi and Dohrn 2008) have found that traditional pastoralists practice flexible management by maintaining flexible physical boundaries for grassland use as well as flexibility in the 
membership of the groups using the rangeland. In contrast to a well-defined, map-hardened boundary, herder traditional boundaries are "fuzzy" (Behnke 1994, Verdery 1999, Mwangi and Dohrn 2008). When adverse climate events happen, pastoralists adjust the boundaries of pastures as well as the size of the user group to allow access to alternative resources when needed. Before grasslands were contracted to individual households, herders in Gacha B shared a larger area of rangeland at the hot level, and connections among the cadres facilitated sharing even larger areas outside the gacha when needed. As Mwangi and Dohrn (2008) noticed, the fuzzy characteristics of herder pasture boundaries are not ambiguous but flexible, i.e., users know clearly who has the right to what, when, and on what terms. Although property is about the boundaries between self and nonself, self is not necessarily individual but can also be collective. In terms of how fuzzy property rights systems work, the models and theory proposed by the new institutionalist and Nobel laureate Elinor Ostrom (1990) support this logic of collective action. Policies based on the tragedy of the commons narrative, ranging from regulatory constraints and rationalization programs to privatization and quasi-privatization, can ultimately cause the loss of social relations that support the capacity of communities to manage common-pool resources (McCay and Jentoft 1998).

The practice of otor is a way of adjusting the boundaries of pasture access among users. In fact, otor reflects the need of herders to access resources through flexibility of physical boundaries as well as in user membership in a highly variable and unpredictable environment or resource pool. In contrast, the property rights model of one parcel of pasture for each household established a hardened, inflexible boundary both for the resources and the user group. This weakened the ability of herders to use flexible spatial scale or mobility to benefit from grassland resources, resulting in a tragedy of rangeland deterioration and impoverished households. Unfortunately this model for grassland contracting has been extended from Inner Mongolia to Ningxia, Gansu, Xinjiang, and Tibet (Yan et al. 2005).

Pastoral social-ecological systems in Inner Mongolia's arid lands are characterized by institutions that enable the flexibility and mobility needed to use resources across a scale large enough to mediate the resource flow from livestock using an environment with high spatial and temporal variability in forage and water resources (Zhang and
Li 2009). Referring to the generic vulnerability framework proposed for this special issue, herder households in Gacha B have lost valuable social assets in terms of the ability to conduct otor based on reciprocal social relations, and biophysical assets because they have lost access to extensive rangelands. Though they have gained the right as a household to a small area of grazing land, they have lost the web of means, processes, relations, and ecosystems they need to benefit from rangelands. This constriction of social and ecological connections has reduced their ability to tolerate climatic shocks and sustain herd productivity using an unpredictable nonequilibrium environment. Institutions such as otor, which enable herders to escape an environmental crisis and create feedbacks that strengthen social relations and the institution itself, are severely threatened by property-rights restructuring. The inability to roam extensive areas and to conduct otor increases localized pressure on rangelands, threatening their resilience by causing soil loss and preventing the recovery that might occur while livestock are absent for a period. The system is moving in the direction of increased vulnerability to environmental change.

\section{CONCLUSIONS}

Recognition that community failure, rather than market failure, can better explain the causes of environmental problems in resource-dependent societies (McCay and Jentoft 1998), demands movement away from policies of fragmentation and privatization of rangelands and toward policy and management that fosters the kinds of horizontal, herder to herder, social relations that have enabled long-term pastoralist persistence in rangeland areas across the globe. Understanding the feedbacks and relations that support or detract from the resilience of pastoralist systems means that policy and management must shift from attempting to control changes in systems that are assumed to be capable of stability, such as fixed stocking rates on fixed pastures, to a more realistic viewpoint aimed at sustaining and enhancing the capacity of socialecological systems to adapt to the uncertainty and surprise characteristic of nonequilibrium rangelands (Adger et al. 2005). Climate change adds another source of unpredictability to the challenges herder institutions were adapted to manage, at a time when those institutions are being dismantled by propertyrights restructuring. 
This study illustrates how misleading assumptions and models may be translated into public policy in a way that reproduces and extends the tragic conditions the policy seeks to remedy, and how state and market forces have played a critical role in eroding the capacity for collective action in communities. The herders of Gacha B have lost their ability to benefit from the rangelands they can now, for first time ever, say they possess as a household. In arid rangelands, the herder "competes" with the environment, and relies on social relationships to succeed. Instead, state and market forces are driving herders to compete with each other, and they are increasingly succumbing to the forces of the environment.

Responses to this article can be read online at: http://www.ecologyandsociety.org/voll6/iss2/art1/responses/

\section{Acknowledgments:}

The research is supported by the Natural Science Foundation of China (40871252) and Ford Foundation. We thank Xie Yina, Zhang Qian, and Li Yanbo for their help with the field survey. A special thanks must go to all the hospitable Mongolian herders, who are always patient with our endless questions.

\section{LITERATURE CITED}

Adger, W. N., T. P. Hughes, C. Folke, S. R. Carpenter, and J. Rockström. 2005. Socialecological resilience to coastal disasters. Science 309(5737):1036-1039.

Banks, T. 2001. Property rights and the environment in pastoral China: evidence from the field. Development and Change 32:717-740.

Behnke, R. H. 1994. Natural resource management in pastoral Africa. Development Policy Review $12: 5-27$.

Behnke, R. H. 2008. The drivers of fragmentation processes in semi-arid and arid landscapes. Pages 305-340 in K. Galvin, R. Reid, R. Behnke, Jr., and T. Hobbs, editors. Fragmentation in semi-arid and arid landscapes: consequences for human and natural systems. Springer, Dordrecht, The Netherlands.

Behnke, R. H., Jr., and I. Scoones. 1993. Rethinking range ecology: implications for range management in Africa. Pages 1-30 in R. H. Behnke, Jr., I. Scoones, and C. Kerven, editors. Range ecology at disequilibrium: new models of natural variability and pastoral adaptation in African savannas. Overseas Development Institute, London, UK.

Bijoor, N., W. J. Li, Q. Zhang, and G. Huang. 2006. Small-scale co-management for the sustainable use of Xilingol Biosphere Reserve, Inner Mongolia. AMBIO 35:25-29.

Briske, D. D., S. D. Fuhlendorf, and F. E. Smeins. 2005. State-and-transition models, thresholds, and rangeland health: a synthesis of ecological concepts and perspectives. Rangeland Ecology \& Management 58(1):1-10.

Chen, J. R. 1987. Selective collections of official documents on livestock husbandry of the Inner Mongolian Autonomous Region. [Title translated from the Chinese: NeiMengGu XuMuYe WenXian ZiLiao XuanBian]. Volume X. Pages 245-252. Compiled by: Policy Study Division of Communist Party Committee of Inner Mongolian Autonomous Region [NeiMengGu DangWei ZhengCe YanJiu Shi]. Hohhot, Inner Mongolia.

Coppock, D. L., J. E. Ellis, and D. M. Swift. 1986. Livestock feeding ecology and resource utilization in a nomadic pastoral ecosystem. Journal of Applied Ecology 23(2):573-583.

Dougill, A. J., E. D. G. Fraser, and M. S. Reed. 2010. Anticipating vulnerability to climate change in dryland pastoral systems: using dynamic systems models for the Kalahari. Ecology and Society 15(2): 17. [online] URL: http://www.ecologyandsociety.org/ vol15/iss2/art17/.

Ellis, J. E., and D. M. Swift. 1988. Stability of African pastoral ecosystems: alternate paradigms and implications for development. Journal of Range Management 41(6):450-459.

Fernandez-Gimenez, M.E. 1999. Reconsidering the role of absentee herd owners: a view from Mongolia. Human Ecology 27(1):1-27. 
Fernandez-Gimenez, M. E. 2002. Spatial and social boundaries and the paradox of pastoral land tenure: a case study from postsocialist Mongolia. Human Ecology 30(1):49-78.

Fernandez-Gimenez, M. E., and S. Le Febre. 2006. Mobility in pastoral systems: dynamic flux or downward trend? International Journal of Sustainable Development and World Ecology 13 (5):341-362.

Gillson, L., and M. T. Hoffman. 2007. Rangeland ecology in a changing world. Science 315:53-54.

Ho, P. 2001. Rangeland degradation in North China revisited? A preliminary statistical analysis to validate non-equilibrium range ecology. Journal of Development Studies 37(3):99-133.

Humphrey, C., and D. Sneath. 1999. The end of nomadism? Society, state and the environment in inner Asia. Duke University Press, Durham, North Carolina, USA.

Huntsinger, L., L. C. Forero, and A. Sulak. 2010. Transhumance and pastoralist resilience in the western United States. Pastoralism: Research, Policy, and Practice 1:1-15.

Li, W. J., S. Ali, and Q. Zhang. 2007. Property rights and grassland degradation: a study of the Xilingol Pasture, Inner Mongolia, China. Journal of Environmental Management 85:461-470.

Li, W. J., and Q. Zhang. 2009. Unscrambling the grassland dilemma: understanding problems of grassland utilization and management in arid and semiarid areas. [Title translated from the Chinese: JieDu CaoYuan KunJing: DuiYu GanHan Ban GanHan CaoYuan LiYong He GuanLi RuoGan WenTi De RenShi]. Economic Science Press [JingJi KeXue ChuBanShe] Beijing, China.

McCay, B. J., and S. Jentoft. 1998. Market or community failure? Critical perspectives on common property research. Human Organization 57(1):21-29.

Ministry of Agriculture. 1996. Department of Animal Husbandry and Veterinary Medicine, data archives. Ministry of Agriculture, Beijing, China.

Ministry of Agriculture. 2007. National Rangeland Monitoring Report 2006. [Title translated from the
Chinese: QuanGuo CaoYuan JianCe BaoGao 2006]. Ministry of Agriculture, Beijing, China.

Mwangi, E., and S. Dohrn. 2008. Securing access to drylands resources for multiple users in Africa: a review of recent research. Land Use Policy 25:240-248.

Ostrom, E. 1990. Governing the commons: the evolution of institutions for collective action. Cambridge University Press, Cambridge, UK.

Ribot, J. C., and N. L. Peluso. 2003. A theory of access. Rural Sociology 68(2):153-181.

Roe, E., L. Huntsinger, and K. Labnow. 1998. High reliability pastoralism. Journal of Arid Environments 39(1):39-55.

Sandford, S. 1983. Management of pastoral development in the third world. Wiley Press, New York, USA in association with the Overseas Development Institute, London, UK.

Scoones, I. 1994. Living with uncertainty: new directions in pastoral development in Africa. Intermediate Technology Publications, London, UK.

Sjaatad, E., and B. Cousins. 2008. Formalisation of land rights in the South: an overview. Land Use Policy 26:1-9.

Sneath, D. 2000. Changing Inner Mongolia: pastoral Mongolian society and the Chinese state. Oxford University Press, New York, New York, USA.

Stringham, T. K., W. C. Krueger, and P. L. Shaver. 2003. State and transition modeling: an ecological process approach. Journal of Range Management 56:106-113.

Taylor, J. L. 2006. Negotiating the grassland: the policy of pasture enclosures and contested resource use in Inner Mongolia. Human Organization 65 (4):374-386.

Thrupp, L. A. 2000. Linking agricultural biodiversity and food security: the valuable role of agrobiodiversity for sustainable agriculture. International Affairs 76(2):283-297. 
Verdery, K. 1999. Fuzzy property: rights, power, and identity in Transylvania's decollectivization. Pages 53-82 in M. Burawoy and K. Verdery, editors. Uncertain transition: ethnographies of change in the postsocial world. Rowman \& Littlefield, Lanham and Oxford, UK.

Vetter, S. 2005. Rangelands at equilibrium and nonequilibrium: recent developments in the debate. Journal of Arid Environments 62:321-341.

Walker, B., C. S. Holling, S. R. Carpenter, and A. Kinzig. 2004. Resilience, adaptability and transformability in social-ecological systems. Ecology and Society 9(2): 5. [online] URL: http://w ww.ecologyandsociety.org/vol9/iss2/art5/.

Walker, J. W. 1994. Multispecies grazing: the ecological advantage. Sheep and Goat Research Journal, Special Issue 1994:52-64.

Westoby, M., B. H. Walker, and I. Noy-Meir. 1989. Opportunistic management for rangelands not at equilibrium. Journal of Range Management 42:266-274.

Williams, D. M. 2002. Beyond great walls: environment, identity and development on the Chinese grasslands of Inner Mongolia. Stanford University Press, Palo Alto, California, USA.

Xie, Y., and W. J. Li. 2008. Why do herders insist on Otor? Maintaining mobility in Inner Mongolia. Nomadic Peoples 12(2):35-52.

Yan, Z., N. Wu, D. Yeshi, and J. Ru. 2005. A review of rangeland privatization and implications in the Tibetan Plateau, China. Nomadic Peoples 9 (1):31-52.

Ybarra, M. 2008. Violent visions of an ownership society: the land administration project in Peten, Guatemala. Land Use Policy 26:44-54.

Zhang, Q., and W. J. Li. 2009. Hierarchical framework for rangeland management: a case study in Inner Mongolia. Journal of Arid Lands Studies 19 (1):81-84. 